\title{
Impact of the Tsunami on reproductive health
}

\author{
M Carballo M Hernandez K Schneider E Welle
}

J R Soc Med 2005;98:400-403

In the past ten years, increasing attention has been paid to the consequences of man-made disasters (conflicts) for reproductive health - in terms of pregnancy outcomes, sexual violence and sexually transmitted infections ${ }^{1,2}$ - but far less to the consequences of natural disasters such as floods, landslides and earthquakes. Despite the many obvious differences between natural and man-made disasters there are similarities in the way they affect people. In any disaster, one public-health imperative is to understand and respond to the reproductive health needs of women and girls, men and boys, and lessons should be learned from the effects of the Tsunami that struck Indian Ocean countries on 26 December 2004.

The concept typically covers pregnancy and motherhood, gynaecological care, child spacing and family planning, sexually transmitted infections and HIV/AIDS, and adolescent reproductive health. Other issues that merit consideration in the wake of disasters are vulnerability, gender violence and poor access to care.

\section{FEMALE VULNERABILITY}

For various reasons, women were at much greater risk of death in the Tsunami than other people. The ratio of female to male deaths was $3: 1$ and in some communities only women are reported to have been killed. ${ }^{3}$ Surviving women may also have become more vulnerable than other survivors to a range of social and economic threats, and most of those who survived have been thrust into unemployment and poverty. Unlike men in these countries, many were unaccustomed to swimming or to being in the water other than to bathe. Also, the clothes they wore and their culturally prescribed long hair became entangled in tree branches and other debris. In some coastal communities, moreover, there are stories of women running back to the beach to search for missing children when the first wave receded, only to be caught by the second wave when it struck. The vulnerability of women who survived is also an issue of concern in relation to sexual violence and rape, and with respect to their economic livelihoods. Everywhere in the region people have been thrust back or further into

International Centre for Migration and Health, Route du Nant d'Avril, $\mathrm{CH}-1214$ Vernier (Ge), Switzerland

Correspondence to: Dr Manuel Carballo, Executive Director, ICMH

E-mail: mcarballo@icmh.ch poverty and for women this may be more problematic than for men. Even in the special camps, the safety of women will remain fragile.

\section{PREGNANCY}

About 150000 women in the countries hardest hit by the Tsunami - namely, Indonesia, Thailand, Sri Lanka, India and the Maldives - would have been pregnant at the time of the disaster, ${ }^{4}$ with 50000 in the third trimester. In India alone, 8300 women in the Tsunami region are estimated to have been pregnant, about 1380 of whom would have been in the last three months of pregnancy. ${ }^{5}$ In Sri Lanka in February 2005, 5000 births were anticipated in the Tsunami-affected population and in Aceh the number of pregnant displaced women was $6000 .{ }^{6}$ Even under normal circumstances a substantial proportion of these women could be expected to experience complications and require emergency obstetric care. In the countries where maternal and neonatal health was a major challenge even before the Tsunami, the likelihood of pregnancy and delivery complications is higher. Maternal deaths in the SE Asia region accounted for one-third of all reported maternal deaths worldwide, and over three million children in the region did not live to see their fifth birthday, dying from preventable causes. ${ }^{7}$

It can be assumed that most of the estimated 40000 pregnant women who survived the Tsunami are now living in displaced persons' camps, with host families, or in makeshift shelters. In the case of Indonesia a total of 133318 women of reproductive age were displaced and of these some 11350 were pregnant (374 deliveries between 3 January and 22 March in Banda Aceh Besar. ${ }^{5}$

Forcible displacement imposes an especially heavy psychosocial and physical load on pregnant women. ${ }^{2,8-10}$ Spontaneous and induced abortion became more likely with their hazard to maternal life; also, babies are more likely to be born preterm or small-for-gestational age. ${ }^{11-13}$ The breakdown in healthcare services and the confusion that typically surrounds forced displacement also reduces the chances of perinatal risk factors being identified and responded to promptly. ${ }^{14}$

\section{HEALTHCARE}

The poverty of some of the communities affected by the Tsunami meant that their access to good-quality care was 
always precarious, and maternal and infant mortality rates were already high. As a result of the Tsunami, coverage by health services in certain locations is now even less secure. In Sri Lanka, for example, 100 medical personnel were killed and 4 out of 8 maternity clinics on the east coast were destroyed or prevented from functioning. ${ }^{15,16}$

In Indonesia, where only two-thirds of births were attended by trained personnel in pre-Tsunami times, the situation may now be even worse because of the very high loss of life among the midwives in the area. At least 1650 midwives died or are still missing, and the total complement of midwives in the region is down by onethird. The midwives who did survive still have difficulty in getting around because of debris; pregnant women are harder to reach than before. ${ }^{17}$ On the other hand, experience elsewhere suggests that the arrival of medical relief teams and health programmes from outside the region (national or international) and the organization of care within camps will have improved pregnancy-related health ${ }^{18}$ and health in general.

\section{SEXUAL VIOLENCE}

Sexual violence occurs everywhere in the world, but in situations of chaos and forced displacement the risk is heightened. ${ }^{19}$ In Sri Lanka after the Tsunami, a reported increase in rape ${ }^{20}$ led several local and international groups to request a refocusing of relief to provide more protection for women. ${ }^{17}$ Reports of sexual attacks on displaced women have also come from Indonesia, ${ }^{21}$ and there are indications that similar behaviour is emerging elsewhere though less assiduously reported. The implications of sexual violence are many. Women (or men) suffer both physical and psychosocial damage: their integration in the community is affected and their ability to find work is reduced. ${ }^{22}$

\section{CONTRACEPTION AND FAMILY PLANNING}

Patterns of contraceptive use varied considerably before the Tsunami (Table 1). On the whole, contraceptive take-up and use rates were highest in India, Thailand and Indonesia, where national authorities endorsed and actively promoted family planning. In Thailand, for example, the contraceptive prevalence rate in 1997 was 70\% and in Indonesia in 2003 it was $57 \%$ (married couples). The damage done by the Tsunami has altered much of this. In many locations, medical drugs and contraceptive supplies were lost and weeks if not months have gone by without any active replenishment of stocks or follow-up of contraceptive users. As in previous disasters, many relief operations have not regarded the early distribution of contraceptive methods as a priority. Couples and individuals have therefore experienced an interruption of contraception even though their sexual activity may be unchanged or higher than before.
Table 1 Pre-Tsunami reproductive health data for affected countries [Data source: WHO, World Health Statistics, 2005]

\begin{tabular}{|c|c|c|c|c|c|c|}
\hline \multirow[b]{2}{*}{ Country } & \multicolumn{2}{|c|}{$\begin{array}{l}\text { Antenatal } \\
\text { care } \\
\text { coverage }\end{array}$} & \multicolumn{2}{|c|}{$\begin{array}{l}\text { Births attended } \\
\text { by skilled health } \\
\text { personnel }\end{array}$} & \multicolumn{2}{|c|}{$\begin{array}{l}\text { Contraceptive } \\
\text { prevalence rate }\end{array}$} \\
\hline & $\begin{array}{l}\text { Per } \\
\text { cent }\end{array}$ & Year & $\begin{array}{l}\text { Per } \\
\text { cent }\end{array}$ & Year & $\begin{array}{l}\text { Per } \\
\text { cent }\end{array}$ & Year \\
\hline India & 65 & 1999 & 43 & 2000 & 43 & 1999 \\
\hline Indonesia & 97 & 2003 & 66 & 2003 & 57 & 2003 \\
\hline Malaysia & - & - & 97 & 2001 & - & - \\
\hline Maldives & 98 & 2001 & 70 & 2000 & - & - \\
\hline Sri Lanka & - & - & 97 & 2000 & - & - \\
\hline Thailand & - & - & 99 & 2002 & 70 & 1997 \\
\hline Somalia & - & - & 34 & 1999 & - & - \\
\hline
\end{tabular}

Assumptions about sexual behaviour after disasters - that people engage in sexual activity either more or less frequently than beforehand-remain largely unproven. What is known, however, is that in many disasters people seek emotional support and often enter into casual sexual relationships that are risky in terms of both unwanted pregnancy and sexually transmitted infections. The tendency for women to be forced into unwanted sexual relationships means that the need for emergency contraception and HIV post-exposure prophylaxis is also greater.

In January 2005, a month after the disaster, UNFPA in Indonesia appealed for more attention to be given to the demand and need for contraception. It estimated that Banda Aceh was receiving only 16000 units out of a requested 80000 at a time when UNFPA believed sexual activity was increasing.

\section{REVERSING STERILIZATION}

The Tsunami not only killed women in disproportionately large numbers but also many children. ${ }^{23}$ As a result, many surviving adults now find themselves childless but unable to bear further children because they have been sterilized. In Tamil Nadu, for example, about $44 \%$ of the women who had already had two children had been sterilized by the age of 27 (the total fertility rate of Tamil Nadu had been effectively reduced from 3.8 in 1976 to 2.0 in 2002). ${ }^{24}$ In the same State, 2300 children under the age of 18 died in the Tsunami and the proportion of children under 12 who died was even higher. The death of children can mean loss of social status and self-esteem for the mother, and also loss of economic security in old age. In response, the government of India instituted measures to give women 
access to reversal of tubal ligation. 189 women have so far applied for surgery. ${ }^{24}$

\section{SEXUALLY TRANSMITTED INFECTIONS AND HIV}

There is a growing concern that the community disruption caused by disasters creates social conditions propitious for the spread of sexually transmitted infections and HIV/ AIDS. ${ }^{4,25}$ Whether this is the case in the countries affected by the Tsunami remains to be seen, but women are in a fragile position. The poverty and isolation of many women may lend itself, as it has done elsewhere in disaster settings, to their having to sell sex or allow themselves to be sexually exploited. Overcrowded living conditions may also contribute to promiscuity and consequent spread of sexually transmitted infections. Other factors that could play a role include the arrival of military personnel, relief and reconstruction workers, and transport personnel. ${ }^{24,26}$ Also, with the large numbers of injuries, HIV-contaminated blood may have been used inadvertently ${ }^{27}$ in settings where there were insufficient facilities for testing and too little time to wait for supplies from elsewhere. Exacerbating factors are the poor general awareness of HIV/AIDS and the fact that condom distribution to displaced people has not been given high priority in most of the countries. ${ }^{26}$

Much will depend on the prevalence of these diseases before the Tsunami. In the case of Indonesia, Sri Lanka and the Maldives the prevalence of HIV/AIDS was low, but both Thailand and Tamil Nadu (India) had relatively high rates. In Phuket, 5\% of migrant women and 9.5\% of fishermen had been previously estimated to be HIVinfected $^{26}$ and in Tamil Nadu $8 \%$ of injecting drug users and $9 \%$ of female sex workers had been reported to be HIVinfected. ${ }^{28}$

\section{MISP AND REPRODUCTIVE HEALTH KITS}

One of the challenges to effective protection of reproductive health in disasters has been defining what to do, when and with what level of priority. The concept of a Minimum Initial Service Package emerged in 1995 through the medium of an Interagency Symposium on Reproductive Health in Emergency Situations. The MISP and the Emergency Reproductive Health Kit (which was created a year later by an Interagency Working Group on Reproductive Health in Refugee Situations and then taken up by UNFPA) were designed to address the most pressing reproductive health needs of women and men in disaster settings. The MISP focuses on how to prevent and manage the consequences of sexual and gender-based violence, how to reduce transmission of HIV through universal precautions and condoms, and how to facilitate clean and safe deliveries.

UN and other agencies also collaborated on the have now been effectively used in man-made disasters (Bosnia, Albania, Macedonia, Sierra Leone, Liberia, and Congo). Their value in terms of concept, product and process has been confirmed most recently in the Tsunami, and hospitals and clinics as well as displaced-persons facilities were able to replace lost equipment and/or benefit from new materials. The kits are made up of twelve subsets that include: field administration of reproductive health; male and female condoms; clean delivery; rape treatment; oral and injectable contraception; treatment of sexually transmitted infections; clinical delivery; intrauterine devices; management of miscarriage and complications of abortion; suture of tears (vaginal and cervical) and vaginal examination; vacuum extraction delivery; referral level kits; and blood transfusion kits. ${ }^{29}$

\section{HYGIENE KITS}

Experience in other recent disasters (man-made and natural) has highlighted the special biosocial needs of women and girls with respect to personal hygiene. Forced displacement typically involves losing access to the personal hygiene supplies women need, and to address this UNFPA has experimented with packages that can be made up with locally procured materials that include sanitary pads, soap and towels. In the context of the Tsunami many local UNFPA offices developed hygiene kits that included additional materials that women said were essential to being able to function with dignity. In Indonesia, where many women had lost everything, the kits included longsleeved blouses or shirts, head scarves, material that could be used as sarongs, underwear, and prayer mats as well as the basic hygiene ingredients. A similar evolution of these kits took place in Thailand and Sri Lanka and also in the Maldives, where a special mother/baby kit was developed. The introduction of hygiene kits is widely recognized as having been an important boost to the morale of women. By 24 June, UNFPA had distributed over 250000 of these kits. $^{22}$

\section{CONCLUSIONS}

The Tsunami affected reproductive health in many ways. It caused sex-specific death on a scale that has devastated families and family life. In doing so it placed many people in a new type of vulnerability that will require highly creative policies and strategies to overcome. It also devastated many of the healthcare services that are essential to sound antenatal care and delivery, killing large numbers of midwives in Indonesia and medical personnel in other countries, and destroying vital physical infrastructures.

In disrupting so many families and communities and causing one of the greatest displacements of people ever seen, the Tsunami also created conditions that are likely to 
bring new threats and challenges to women and girls. Securing their health will have to include protection as well as good-quality healthcare.

Many relief organizations failed, as in previous disasters, to give adequate priority to reproductive health. The various complements are vital to individual, family and public health, and their neglect will only set back the health reconstruction effort, especially in populations where the reproductive health indicators were cause for concern even before the Tsunami.

Acknowledgments We thank the participants of the ICMH Tsunami Expert Review Committee meeting that took place in Male, Maldives, 22-24 April and the Taiwan International Health Operations Center and others for their support of this project.

\section{REFERENCES}

1 McGinn T. Reproductive health of war affected populations: what do we know? Int Fam Planning Persp 2000;26(4)

2 Carballo M, Simic, S. Health in countries torn by conflict: lessons from Sarajevo. Lancet 1996;348:872-5

3 Nath L. Voluntary Health Association of India Tsunami Report. ICMH Expert Review Meeting on Public Health Impact of the Tsunami. Geneva: ICMH, 2005

4 Lalasz R. The Indian Ocean Tsunami: Special Challenges for Women Survivors. January 2005. Connecticut: Population Reference Bureau, 2005

5 International Centre for Migration and Health. Interim Report of a Meeting on Public Health Impact of the Tsunami. Geneva: ICMH, 2005

6 Tsunami may yield baby boom. Red Nov, 5 February 2005

7 World Health Organization Regional South-East Asia Press Release, New Delhi/Geneva. 10 February 2005. Geneva: WHO, 2005

8 Cordero JF. The epidemiology of disasters and adverse reproductive outcomes: lessons learned. Envir Health Persp 1993;101(suppl 2):131-6

9 Meyers J, Lobis S, Dakkak H. UN process indicators: the key to measuring maternal mortality reduction. Forced Migration Review 19 January 2004

10 Chang H-L, et al. Psychiatric morbidity and pregnancy outcome in disaster areas of Taiwan 921 earthquake. Psychiatry Clin Neurosci 2002;56:193-44
11 Lehmann A. Safe abortion: a right for refugees? Reprod Health Matters 2002; 10:151-5

12 Neuberg M, Pawlosek W, Louszanski M, Neuberg J. The analysis of the course of pregnancy, delivery and postpartum among women touched by the flood disaster in Kotlin Klodski in 1997. Ginekol Pol 1998;69: 866-70

13 Weissman A, Siegler E, Neiger R, Jakobi P, Zimmer EZ. The influence of increased seismic activity on pregnancy outcome. Europ J Obstet Gynecol Reprod Biol 1989;31:233-6

14 Al Gasseer N, Dresden E, Keeney GB, Warren N. Status of women and infants in complex humanitarian emergencies. J Midwifery Women's Health 2004;49(suppl 1):7-13

15 Planet Wire. Tsunami Background Information [www.planetwire.org/ wrap/files.fcgi/5237_TsunamiBackground.htm]

16 Planet Wire. 150,000 Pregnant Women in Tsunami-Affected Areas [www. planetwire.org/details/5234]

17 Global Action on Aging. As Tsunami Recedes, Women's Risks Appear. [www.globalaging.org/elderrights/world/2004/tsunami.htm]

18 O'Heir J. Pregnancy and childbirth care following conflict and displacement: care for refugee women in low resource settings. J Midwifery Women's Health 2004;49:14-18

19 UNFPA. Reproductive Health in Refugee Situations [www.unfpa.org/ emergencies/manual/4.htm]

20 UNFPA. UNFPA Calls for Greater Security for Women Affected by Tsunami. [www.unfpa.org/news/news.cfm?ID=541\&Language=1]

21 Daily Times (Pakistan). Sexual abuse rife in Aceh tsunami camps [www. dailytimes.com.pk/default.asp?page=story_27-3-2005_pg4_11]

22 UNFPA. Six Months After the Tsunami: UNFPA Helps Restore Reproductive Health Capacity and Promotes Women's Rights [www.unfpa.org/news/ news.cfm?ID=636]

23 US Pharmd. Indian State offers reverse sterilizations. 2 March 2005

24 Cohen M. After the Tsunami: a drive to reverse tubal ligations in Tamil Nadu. July 2005. Connecticut: Population Reference Bureau, 2005

25 After the tsunami: HIV prevention and disaster relief. VAX, International AIDS Vaccine Initiative Newsletter [www. iavireport.org] 2005;3:1-3

26 UNDP. AIDS Risk May Increase says $U N$ [www.undp.org/bcpr/disred/ documents/tsunami/thailand/pr240104.pdf]

27 Thomas J. Mainstream HIV prevention into 'Tsunami' response [http://bmi.bmjjournals.com/cgi/eletters/330/7482/59]

28 National AIDS Control Organization, India. Observed HIV Prevalence levels State wise 1998-2004 [www.nacoonline.org/facts_statewise. $\mathrm{htm}]$

29 Inter-agency global evaluation of the reproductive health services for refugees and internally displaced persons. Evaluation of the use of the Minimum Initial Service Package (MISP) and RH kits in postemergency situations, November 2004 